\title{
Roses and Castles: Competing visions of canal heritage and the making of place
}

Abigail Wincott (corresponding author), University of Brighton ${ }^{1}$. Twitter: @ abigailwincott https://orcid.org/0000-0002-3162-644X

Neil Ravenscroft, University of Brighton ${ }^{2}$ http://orcid.org/0000-0001-7196-8420

Paul Gilchrist, University of Brighton, Twitter @ paulgilchrist.

This is an Accepted Manuscript of an article published by Taylor \& Francis Group in the International Journal of Heritage Studies on 28/11/2019, available

online: http://dx.doi.org/10.1080/13527258.2019.1693412.

\begin{abstract}
This article evaluates the cultural politics of waterfront heritage in regenerating Manchester, UK, in order to understand why the benefits envisaged for local communities have not been fully realised. Analysing a database of texts produced for an EU cultural heritage project (2015-2017) we find there is no lack of rich and diverse cultural heritage in Manchester, produced by a broad range of people. Using Lefebvre's (1991) ideas about the social production of space we explore how, nonetheless, waterfronts as heritage spaces are produced in ways that exclude that variety, and thus place and displace people, socially as well as bodily. We propose a role for geolocated mobile apps for spatialised heritage storytelling to enable communities to make their mark on official, imposed representations of space. Our analysis has relevance for cities across the globe, as governments, investors, redevelopment quangos and others seek to use urban waterways as heritage assets to reinvigorate former industrial areas, without adequate appreciation of their full range of cultural meanings.
\end{abstract}

Key words: placemaking, industrial heritage, canals, multimedia

Funding details. This work was supported by the AHRC under Grant AH/N504397/1.

\section{Introduction}

On a dull December day in the Ancoats area of Manchester, our research diary records that we are struck by a contrast. On Redhill Street, the imposing castle-like redbrick Royal Mills building has been renovated and converted to offices and an artisanal coffee shop. Next door, the huge Murray Mills complex is undergoing renovation. Across the Rochdale Canal,

\footnotetext{
${ }^{1}$ Abigail Wincott is now at Falmouth University, abigail.wincott@falmouth.ac.uk

${ }^{2}$ Neil Ravenscroft is now at the Royal Agricultural University
} 
minimalist concrete and wood walkways and footbridges edge a new canal basin, and rising above this tidy urban waterscape, tall apartment blocks are being built; hoardings around the site promising vibrant urban living. Bobbing beneath these huge structures are a row of brightly painted canal boats. Unlike the muted tones of the built environment, the boats are painted in clashing colours - pink and orange, blue, red. Some are decorated with flowers or romantic landscapes in the style known as 'roses and castles' (Young 2003) [Insert fig 1 near here. Caption: Roses and Castles artwork on a canal boat, photo by David Dixon (CC BY SA 2.0)]. The names of the boats are sometimes humorous; often they have women's names.

They reveal intimate signs of habitation such as potted herbs, wet shoes, firewood, mugs, and ornaments and there are net curtains in the windows. They seem very small and even vulnerable, beneath the new apartment blocks and refurbished mill buildings. All in all, they are both in place, in a physical and historical sense, and also out of place in terms of contemporary culture.

Using this observation as a starting point, we seek to argue in this paper that it is this very dualism - of being simultaneously in and out of place in contemporary post-industrial urban spaces (Cresswell 1996) - that is at the core of a new and potentially divisive form of heritage-led regeneration. In this new place-marketised environment (Atkinson, Cooke, and Spooner 2002), it seems to us that the repurposing of historic buildings (Pendlebury, Wang, and Law 2017, 2) is no longer solely related to creating acceptable narratives of their former uses (Kearns, Joseph, and Moon 2010; Joseph, Kearns, and Moon 2013), but now extends to re-imaging - and repositioning - the very communities which these historic buildings formerly served. Using what De Cesari and Dimova $(2018$, 863) have termed the process of 'heritagisation', in this case of Manchester's largely hidden heritage of minor waterways, we wish to contribute to the current debate, in this and other journals, by arguing that not only is the redevelopment of Manchester's minor waterways consistent with what Pendlebury, Wang, and Law $(2017,212)$ have termed 'uncomfortable heritage,' but that it extends the scope of this term to include both tangible and intangible heritage.

Our starting point is that despite recent debates there remains a lack of critical reflection about the project of canal heritage development as a social and cultural, as well as an economic, phenomenon (Cosgrove and Daniels 1988; Schama 1995; Vallerani 2004; Frolova 2008). Despite decades of canalside investment in Manchester and other such cities, there are few indications that local people experience the claimed benefits, in terms of improved quality of life. Yet, at the same time, the drastic remodelling of post-industrial canalside zones has displaced many former communities, with little attention given to the needs of those moving in to replace them. Based on a case study of the Ancoats area of Manchester, we thus seek in this paper to offer a space for the critical reflection that is currently lacking. In so doing we seek to juxtapose two competing visions of the canals, focussing on the regenerated waterscape of repurposed buildings and the alternate, intimate and mobile, spaces of water-based communities. These are at once the imagery conjured up by the boats as 
artefacts and also a signifier of separation, between the boats themselves and the essential mobility of the waterscapes that they once inhabited. We will first review the current debates in order to locate our argument, after which we will explain our evidence base and approach, before focusing on a detailed analysis of the juxtaposition. Through this juxtaposition we hope to address the research question of why it is that, given the known rich and varied cultural heritage of canals, heritage-led placemaking in Manchester has not been successful in making places that have contemporary meaning - to those resident communities who are impacted by change as well as to incomers who have no family or community connections to these heritage spaces. In addressing this question we seek to add to current debates about the wider, non-economic, impacts of place marketing (see Atkinson, Cooke, and Spooner 2002; Pendlebury, Townshend, and Gilroy 2004; Pendlebury, Wang, and Law 2017; Kearns, Joseph, and Moon 2010; Waterton and Smith 2010; Rautenberg 2011; Joseph, Kearns, and Moon 2013; Mengüşoğlu and Boyacioğlu 2013; De Cesari and Dimova 2018; Leeson 2018; Meskell 2018), particularly in terms of confronting the uncomfortable (or inconvenient) heritage represented by local people and artefacts, which can be seen as out of place in new city images.

\section{Place-making and the 'uncomfortable heritagisation' of waterside communities}

As Mengüşoğlu and Boyacioğlu (2013) have observed, with respect to Manchester's industrial built heritage, the reuse of former industrial buildings is connected with the creation of new landscapes that contribute to the repositioning of cities away from their industrial past and towards new creative and symbolic economies (Zukin 1995; Atkinson, Cooke, and Spooner 2002; Florida 2002). As the world's first industrial city, Manchester has a considerable legacy of industrial buildings, mainly located adjacent to canals and waterways. Indeed, Manchester's canals were significant in shaping its early industrial development. Canal companies were innovative in creating comprehensive waterside infrastructure enabling the efficient transportation of raw materials to, and goods from, adjacent factories, few of which were more than 20 yards from a canal (Maw, Wyke, and Kidd 2009; Maw 2013). The material legacy is a city of red brick factories and warehouses that radiate along Manchester's waterways; a specific architecture that has come to define the image of Manchester as the archetypal Victorian industrial city (Crinson and Tyrer 2005; Rose, Faulkener, and Holder 2011; Mengüşoğlu and Boyacioğlu 2013).

Significant attention has been given to safeguarding and restoring this material culture, which includes buildings, bridges, tunnels and other physical remains of the canal network, and which in its entirety Nevell $(2013,1)$ regards as a 'linear transport monument of the Industrial Age'. This practice is now so widely accepted that in recent decades many millions of pounds have been spent restoring and maintaining similar industrial-age canal networks, their towpaths and associated built environment in cities round the world (Inland Waterways Advisory Council 2010; Hazenberg and Bajwa-Patel 2014). 
In addition to their historic value, many contemporary benefits of canal heritage have been identified (Canal and River Trust 2014). These benefits include leisure, education and community development (Button and Pearce 1989; O'Gorman, Bann and Caldwell 2009; British Waterways 2011). However, in Manchester, as in many other post-industrial cities, canals have come to be seen as assets to property-led economic regeneration schemes (Larkham and Lilley 2003; Crinson and Tyrer 2005; Fainstein 2008; Mengüşoğlu and Boyacioğlu 2013; Ward and Swyngedouw 2018), particularly in underpinning notions of redeveloped water- and canal-sides as successful and vibrant places replete with waterside bars and restaurants, offices and apartments overlooking the water (Hoyle, Hussein, and Pinder 1988; Buckman 2016). As Atkinson, Cooke, and Spooner $(2002,27)$ observe, in their work on the appropriation of specific and stylised aspects of waterways and watersides in place-making and place-boosterism, the use of heritage buildings and landscapes in place marketing is based on accentuating aspects that investors, tourists and incomers are likely to find attractive, while 'disguising' the 'dark' or 'shadow' elements that are deemed unattractive (see Ashworth, Kavaratzis, and Warnaby 2015; Lucarelli 2017; Vanolo 2017). More recently this theme has been developed by De Cesari and Dimova (2018) who have coined the term 'heritagisation' to describe the process of gentrifying stigmatised historic buildings and city quarters into desirable places for wealthy incomers to live. As they observe:

Today policymakers worldwide assume that heritage and culture are resources that can stimulate local socio-economic development and that the creative classes foster creative economies that are locally-tuned and sustainable over the long term (De Cesari and Dimova 2018, 2)

While landowners and developers reap the financial benefits of this transformational process, it has been widely observed that this is often - usually - at the expense of the local communities that are marginalised or displaced (Leeson 2018; Meskell 2018). As Waterton and Smith $(2010,9)$ have argued, this marginalisation is just as much a part of heritage-led regeneration as the gentrification of buildings, because it is about 'misrecognising' local people as a means of dissociating them from the newly heritagised properties. For us, this misrecognition extends to material artefacts, such as the boats that we observed near Murray Mills and the shoes, pot plants and ornaments arrayed on them. This is an extension of what Pendlebury, Wang, and Law $(2017,2)$ have termed 'uncomfortable heritage' which they use to denote the process of conceptualising ... the problem of reuse, remembering and forgetting as a building with 'an unsavoury past' is re-presented, its meanings changed. In this way, they argue, the 'uncomfortable' past use of a building - as a warehouse built on the profits of empire and the subjugation of local workers, for example (see Mengüşoğlu and Boyacioğlu 2013) can be selectively 'forgotten', with new, more benign, stories remembered and promoted (see also Kearns, Joseph, and Moon 2010; Joseph, Kearns, and Moon 2013). 
'Uncomfortable' cultural histories and their associated intangible heritages have also been marginalised through an oversimplification of the concept of 'community', that mystifies and naturalises existing power relations and others those outside of heritage professionals and the white middle classes, who appear as if outside 'community' (Waterton and Smith 2010, 9). This, then, is our starting point: the contrast between the increasingly well-understood reimagining processes underpinning heritagisation and city boosterism, and the much less well understood ways in which these processes impact on the communities living, working, those with a longstanding relationship to the area and newcomers. In framing this issue we developed a research question about why it is that the regenerative place-making project in Manchester has not been more successful in making places that have contemporary meaning - to local residents as well as to incomers. In addressing this question in the next section we will set out the case study and the methods we used to generate a database of materials representing the range of canal heritage discourses in Manchester, before moving on to use Lefebvre's trialectic to interrogate the significance of the apparent clash between the boats and buildings that we introduced above.

\section{The case study: the canals of East Manchester}

The Ancoats project, which took place between 2015 and 2017, was part of a larger collaboration between researchers and navigation authorities designed to explore the cultural significance of Europe's lesser-known waterways. The research partners in the UK were the University of Brighton and the Canal and River Trust (CRT). The CRT recommended studying the Rochdale and Ashton Canals in Ancoats because canalside regeneration has taken place without any apparent increase in usage by local people. Indeed, there is evidence of a lack of social cohesion and community spirit in the area (Blakeley and Evans 2009). No unified archival repository relating to the canals of Greater Manchester exists, so the researchers used a community facilitation methodology known as the Collaborative Stories Spiral (Gilchrist et al. 2015) to access historical interest groups and heritage networks in order to retrieve tangible data sources, narratives and social memories relating to the canals (Visentin and Eulisse 2018). A purposive sampling approach was used to identify potentially relevant archives and appropriate interviewees on the basis of their ability to contribute to a census of the tangible and intangible waterscape heritage of the Rochdale and Ashton Canals.

Materials were elicited through face-to-face interviews with key stakeholders and volunteer groups, a web review of available digital materials (including waterscapes in fine arts and historic photography), and an investigation into the archival holdings of the Canal and River Trust. Site visits and walks along the towpaths of the canals aided comprehension of their lost histories; with photos and diary reflections created in order to better understand the role of heritage — and available heritage assets and materials — in producing the space (Visentin 
and Peterle 2017). The paper draws upon this extensive and iterative process of gathering, investigating, connecting and experiencing the waterways and their heritage, and is informed by geohumanities approaches in its combination of place, experience and interpretation. The census process produced an inventory of cultural assets relating to the canals that is held on a publicly-accessible database at the University of Leiden ${ }^{[1]}$, with the information used to make a series of digital heritage trails for the general public, created using the izi.travel app ${ }^{[2]}$ and branded 'Waterways Explorer'. Workshops and a training manual produced by the researchers aim to encourage local people to use these trails and create more of their own. Analysing all the materials about the Rochdale and Ashton Canals elicited as described above (but excluding photos and research diaries we produced), we identified a wide range of themes. These included canals as engineering feats, marking points of progress in Britain's technical and industrial progress and conquest over natural terrain. Canals were also popularly drawn into discourses of scenic and nostalgic rural and semi-rural settings in a range of souvenirs and ephemera as well as Instagram images. There is much recent celebration of the 'dark' associations of urban canals, in crime fiction and TV drama, and in photography on Instagram and Flickr aestheticising decay, disuse and graffiti. Finally the urbane vision of the canals dominated in planning and regeneration texts and in the architecture and design of new developments in Ancoats and elsewhere.

Given this richness and variety of canal heritages in a database largely produced through a desk based audit, why is it that the experience of walking the canal in Ancoats produced our notes of a clash or misplacement between the boats and the buildings? In the next section we analyse in more detail the discourses of urbane post-industrial canalside redevelopment and canal boats, in order to understand both the clash and its significance as a symbol of a wider aggressive displacement of people through the mobilisation of a particular and narrow discourse of post-industrial heritage.

\section{Juxtaposing the roses and the castles: The construction of canal heritage in the media and on the ground}

In this section we explore in detail the construction of the dominant canalside heritage discourse of urbane placemaking, which revolves around the refurbishment and showcasing of mighty and fortress-like industrial structures, opening onto the canal. We contrast this with the under-used cultural resources of canal boats, with their vibrant colours, 'feminine' decorative artwork and the mobility of both the boats and the communities of people who use them. This is a juxtaposition we are (half) playfully terming castles and roses, but with serious intent of arguing that contemporary heritage-led redevelopment of cities like Manchester has struggled to contain and erase pluralistic working class cultures, and in doing so has drawn on and reproduced social and cultural inequalities. 


\section{The Castles}

The canals used to be largely hidden from view by the industrial buildings they served, but many of these buildings have been demolished, leaving only a handful, including Royal Mills and Murray Mills, to be redeveloped. They have been refurbished in a particular way, which highlights features of industrial architecture, leaving exposed brickwork and iron girders rather than covering them up. Sometimes winches or other cast iron Victorian machinery are cleaned up, painted and displayed. Much canalside housing, like the nearby Piccadilly Village development between the Rochdale and Ashton Canals, is newly built, but echoes the features of the industrial buildings it replaces. For example, large arched windows evoke the apertures through which chains or ropes ran from the engine house and powered the machinery inside mills and they are all red brick. [Insert fig 2 near here. Caption: Piccadilly Village development, Ashton Canal. Photo by Benjamin Shaw (CC BY-SA 4.0)]. The black terraces of housing by the new marina in New Islington also have prominent first floor windows, and small square balconies that resemble the housing for a winch.

Some housing is low-rise, but where mills are renovated, they rise five or more (very tall) stories above the street. The architectural style is also rather forbidding-sheer cliff faces of red brick, broken only by row upon row of identical windows; they appear rather prison or fortress-like. This is not coincidental - these mills and warehouses were built to be secure, to control the flow in and out of raw materials, finished goods and workers. Murray Mills had only one gated entrance for people. For goods and raw materials, the only way in and out was a tunnel from the Rochdale Canal, which emerged safely within the four wings of the building.

The artists' impressions that precede the renovations of canalsides also emphasise the impressive scale of the buildings, as do promotional photographs of completed developments. They do this by showing them from either very low or very high, oblique perspectives, which has the benefit of fitting in the entire building or buildings, but also accentuates their height and evokes the grandeur of castles or stately homes in promotional brochures (Waterton 2010, 162). Observing the portrayed buildings from an oblique angle and at a distance, the viewer is not invited to be personally involved in the scene. There are a small number of old paintings and drawings of the mills on Redhill Street (formerly known as Union Street), the site of the present-day developments of Royal Mills and Murray Mills. These too emphasise the scale of the buildings with high and low elevations and small human and animal figures. [Insert fig 3 near here. Caption: Mills on present-day Redhill Street, Ancoats. From A Century of fine Cotton Spinning, 1790-1913. McConnel \& Co. Ltd. Photo Wikimedia Commons] During the nineteenth century, people used to come from other European countries to marvel at what were at that time some of the tallest buildings, testament to the power and energy of booming industrial Manchester, a reputation that is repeatedly referenced in claims for Manchester as a major player in the post-industrial age (Madgin 
2010, 43). It is this idea of canalscapes as powerful and impressive that predominates in redevelopment texts.

The ascendance of the grand, industrial aesthetic can be linked to changes in the way urban development and regeneration have been funded. In the late 1980s and 1990s the work of regeneration was partly devolved from Manchester's local government to quangos or the private sector (Madgin 2010, 43). This led to new discourses of regeneration, which shifted from improving the public realm to a language of global competition for resources based on the sort of display and showmanship likely to win major cultural prizes (Lutz 2004; Madgin 2010; Taylor 2013). Like many others, Manchester City Council developed an image-based place making strategy that used the regenerated canalsides as a means of establishing its reputation on the global stage (Hetherington 2007, 633).

The aspects of industrial heritage along the canals in Manchester and elsewhere that are most suited to these competitive redevelopments are not of course the quotidian heritage of working-class life; terraced houses, laundries, public baths, pubs or chip shops. What is most suited to showmanship on a world stage is the myth of Manchester as a powerhouse, and pioneer of intense change, the domination of the land, of raw materials and of people by industrialists and engineers. These tangible and intangible legacies are developed into an aesthetic which juxtaposes the industrial with the sleek look of modern materials, eschews decoration and bright colours for dark tones and hard surfaces that characterises loft apartments and warehouse conversions from New York to Hong Kong. Dynamic, masculine and aspirational, the 'urbane' style calls to young professionals who can help the city realise its ambitions (Mellor 2002), stepping into the shoes of the mercantile and landed classes who dominated in the industrial age.

\section{The roses}

The vivid and clashing colours and decorative features of the boats - the roses and castles (Young 2003) — are so closely associated with the feminine in British culture that the style is often assumed to have its origins in the coming of women to live and work on the boats in the $19^{\text {in }}$ century. Yet contemporary writers document all-male crews living and working on boats nonetheless decorated with flowers, romantic landscapes, net curtains and polished brass work (Lewery 1995). It has also often been assumed to be foreign in origin, brought by gypsies or Eastern Europeans. There is no evidence of this either, and there is a long British tradition of decorating carts and fishing boats with bright colours and decorative scrollwork. Still, amidst the looming mills and the grey waters of the canals, narrow boats butt up against the prevailing myth of acceptable Britishness - 'respectable, reserved and dressed in careful grey' (Lewery 1995, 48). 
It is not only for aesthetic reasons that canal boats pose a challenge to the dominant heritage regime of regenerating Manchester. Boat people were historically often feared or disliked for what we might call today anti-social behaviour (Lewery 1995, 51). Chris Leah of the Wooden Canal Boat Society told us that the people who live on the canals have long had a difficult relationship with the navigation authorities maintaining the waterway. These organisations seek to uphold regulations and collect licence fees from boaters. Yet many people choose to live on a boat as an escape from the constraints of mainstream life, and chafe at the regulation imposed by the navigation authorities.

Thus, canal boats moored in New Islington are an interesting visual reminder of the communities of boat people who worked the canals in the industrial age, a community less well known than the cotton-mill workers of the North West. The latter are referred to in television programmes about the Rochdale canal, Great Canal Journeys and Barging Round Britain, their work, the machinery, their slang and archive photos of mill workers all foregrounding the cotton mill and its routines. This is a world often represented as fixed, the workers living in the shadow of their place of employment, called to work and released from it by whistles and sirens, taking annual holidays to the seaside en masse. But canal communities were also mobile and transient communities, with connections to people in the many towns and cities along the canals. In addition, industrial-era Ancoats consisted of more than mill workers and boat people; it was also home to a varied array of shops and other small businesses, as well as steel working, engineering firms and the Molineaux Webb decorative glass works. This wide range of activity is not well represented in the heritage-led redevelopments of today.

Boats should not only be associated with work. The Canal and River Trust archive has photos of leisure boating trips on the canals from the late $19^{\text {ti }}$ and early $20^{\text {th }}$ centuries, often organised by clubs and associations. Though boats rarely feature in the architectural drawings and promotional images for canalside developments, canal boating made redevelopment possible, because it was canal enthusiasts who campaigned for restoration as a network of leisure canals, at a time when waterways were being filled in and built over. The enthusiasm can still be seen in the popularity of clubs and societies such as the Inland Waterways Association, Friends of the Rochdale 9, the Wooden Canal Boat Society, the Ancoats Canal Project and the Hollinwood Canal Society, which still campaigns for the reinstatement of an as yet unrestored branch of the Ashton Canal. Leisure and pleasure of canals and canalside areas are particularly poorly represented in the material heritage of Ancoats.

There is a plethora of popular representations, including TV programmes, tea towels, jigsaws, prints and social media posts, which celebrate the canals as peaceful, pretty and nostalgic places. This scenic discourse of canals differs from the urbane not only in content. It tends not to use the distant, high and oblique point of view, but low and close, immersing the viewer in the scene. TV programmes immerse the viewer in life on the canals too, using the experiences of the presenter as a proxy. In the opening sequence of the Channel 4 series 
Great Canal Journeys (Alaska TV 2016), actor and presenter Timothy West calls canals 'the antidote to the hurry and bustle of modern life. You can't rush on the canal'. He and his wife and co-presenter, actress Prunella Scales, meet interesting characters along the Rochdale, as does presenter John Sergeant in ITV's Barging Round Britain (Spungold 2014). They characterise the canals as the realm of the individual, the character, the person who doesn't quite conform with the expectations of the modern world, perhaps by being slower, by doing things on foot or by hand, reviving traditional crafts and making traditional foods.

Life on the canal is slow but can be physically taxing, as boating members of the Friends of the Rochdale 9 and the Wooden Canal Boat Society told us. A leak in the canal causes John Sergeant to be stranded for several hours, while in Great Canal Journeys, the many, very deep locks of the Rochdale Canal are enrolled in a narrative of the canal as challenging, even dangerous. At the end of the programme, as they finally reach the summit, the highest point on the canal, the presenters shout 'We've done it!' and admit that it has been 'the hardest canal journey I've ever done'. These narratives represent canals as very special places, outside ordinary routine life, where the individual can make a space for themselves, if they are willing to overcome challenges. This continues a longstanding association of canals with feats of daring and physical prowess, formerly cut jumping and swimming and latterly running and biking.

\section{Analysis and Discussion}

If these many heritages exist side by side, why is the juxtaposition between boats and buildings problematic? It has something to do with the relative power of different discourses to place, displace and replace people, materials and meanings. Henri Lefebvre's writing, particularly the Production of Space (1991) has been used a great deal as an approach to analysing the politics of contested, especially urban, spaces. It is important to think of space like the regenerated canalside of Ancoats not as inert and permanent location where people act, but something that is social and cultural, always being produced and reproduced, contested, re-asserted by the things people do. A locality like Ancoats becomes a relatively enduring space, inscribed by social processes, by an almost-agreement about what these places are like, and whether we belong in them, and what sort of things ought to be done there (Pierce and Martin 2015). Recognising the interplay between everyday life, practices and representations here calls for a more sophisticated understanding of space to capture the dynamic and contested character of urbanisation. This is provided by Lefebvre's (1991) conceptual triad, composed of three facets. First, representations of space is space as articulated in abstract ways by the work of planners, urbanists, academics, business and scientists. Representations include blueprints, maps, plans, codes, and signs. This space can be studied for the prominent ideologies that have intervened in the construction and architecture. Second, spatial practices are about the physical and experiential deciphering of 
space. They cover the routine activities inscribed in a locality and are associated with the perception of space. It is about the spatio-temporal rhythms and the mental and social activity involved in the production of a space. Third, spaces of representation (or, representational space) is about how space is experienced in symbolic ways, covering the images and symbols associated with everyday life and how symbolic and ideational manifestations of space are subverted and opposed by people. The facets provide a way in which to make sense of the dynamics between the planned, routine and everyday and so keeps in play the idea that space is not static, but produced through shifting interplays between enduring materials, imagined and lived realities and cultural representations.

A Lefebvrian approach helps us to better understand the importance of representation to how spaces are produced, because spaces and places are not simply a given, a background in front of which the social and cultural takes place. This seems to help avoid a dualism, where it appears there is a 'genuine' urban Manchester, misrepresented by redevelopment literature, or built over by the resulting buildings. The representations make spaces too.

As this suggests, there are increasingly dominant discourses of canal heritage in play, in which the engineering aesthetic of the canals becomes the backdrop for urbane redevelopment. Planners and developers execute representation of space through their maps and models and have been extremely selective in what they take from the past to project to the present and future. Not only do the urbane redevelopments dominate physically, through their sheer scale, but symbolically they celebrate the might of industrial power over ordinary people and over the natural environment. The overarching myth of canal heritage is a myth of dominance, drawing on historical knowledge of industrial-age feats of engineering, the ascendance of the North West as an industrial hub, of the age of empire. It is the dominance of humans over nature, the masculine over the feminine, the wealthy over the poor and the large over the small. This is achieved through the protection and display of canal infrastructure, mills and cast iron winches. The smaller buildings of the industrial ageterraced houses, shops, pubs and so on-have mostly been demolished to make way for these large-scale redevelopments. The mobile and entrepreneurial boat people too have been erased. This is how the canal boats can come to seem incongruous in New Islington Marina.

This is not inevitable but has been encouraged by the reliance on private investment and a global culture of competitive place-making. Heritage development needs 'assets', both material and abstract, and Manchester's place makers needed to find assets which could impress, with which to make a bold statement of the city's ambition. To do this they have enrolled large and impressive mill buildings, lining the canals. They have drawn on the myth of Manchester as a mercantile capital, which had dazzled the world with its daring and its wealth 150 years before. Aspects of canalside heritage like local pubs or boat trips, which might be more interesting to a wider range of local people, do not cut it when bidding for big prizes. 
Thus it is that the superficial aesthetic of public urbanity has been embraced in regenerating waterfront projects in Manchester and elsewhere. While these projects may reduce the former sense of dereliction experienced by local people, they offer little of substance to many especially children, teenagers and working class men who cannot find work in the professional services economy or the bars, coffee shops and restaurants that serve its workers (Mellor 2002; Kennedy 2004). The representation of space here contrasts with the human needs of spatial practice. Consistent with Florida's (2002) claims about the benefits of attracting creative incomers, these projects pander to a middle class sensitivity that sits uncomfortably in former industrial communities. Heritage discourses do not only make a place (Manchester) but assign to people their proper place within that cityscape (Skeggs, Moran, Tyrer, and Binnie 2004). Either explicitly or implicitly, through place making discourses, people come to know their place. They may be immediately and unquestionably displaced, as when the Cardroom housing estate was demolished to make way for today's New Islington redevelopment, or their local pub or swimming baths close down. Or more subtly, they may perceive that the heritage is not addressed to them; that their place is to pass through or pass round, not to linger.

Urban Splash, one of the main development companies in Ancoats, complicates this picture. Its designs are often playful, integrating multiple cultural references into new buildings. For example the colourful Chips Building on the Ashton Canal in New Islington [insert near here fig. 4 Chips Building. Caption: Chips Building, Ancoats. Photo by David Jones (CC BY 2.0)] is designed to look like a stack of fried chips wrapped in newspaper, presumably in reference to the chip shops that the area used to have or which are especially associated with the towns of the North West of England. The company also planned a self-build competition overlooking the marina called Tutti Frutti. Cancelled following the global financial crisis of 2007-2008, it was intended to bring more architectural diversity to redevelopment (Fairs 2007), and its name referenced the many ice cream businesses run by Italian families locally, which once earned the area the nickname of Little Italy (Rea 1988). These are important interventions, because they reference pleasure and food, and they are playful—something which pricks the pomposity of the urbane. They are however still outnumbered by physical expressions of urbanity. As the Italian community, and other small businesses in the area including chip shops and pubs have almost entirely disappeared following the depopulation and subsequent gentrification of Ancoats, such attempts to reference local communities risk being cultural appropriation, or at least of failing to mean very much in terms of preserving local colour and diversity and integrating professional and working class groups.

The dominant discourse of canalside Manchester also feeds off the 'dark' theme seen in our database analysis. The prevailing myth of Manchester was for a long time as the 'shock city' of the industrial revolution, to use Asa Briggs's (1963) striking phrase. This is Manchester associated with the dynamism and innovation of industrialists and engineers, but also as grime and poverty and suffering, made famous by the so-called 'Condition of England' 
novels of the mid-19th century and Friedrich Engels' The Condition of the Working Class in England. Artists such as L.S. Lowry (1887-1976) and his mentor Pierre Adolphe Valette (1876-1942) depicted an industrial Manchester of smoke and a damp fogginess. Historic England's guide to Ancoats (Rose, Falconer, and Holder 2011) points to the exploitation of working people, pointing out the low door handles for child-workers, still visible in former mill buildings. The thrill of the gritty and broken still pervades fictional depictions of Manchester in recent decades, in TV series like comedy-drama Shameless, which centres on the exploits of a family what is sometimes referred to as the 'underclass'; detective series Life on Mars and Ashes to Ashes and the crime fiction of Val McDermid. In crime fiction, after all, canals are somewhere bodies are dragged out of and abandoned industrial buildings the setting for gangland interrogations. Within the gentrifying discourse of post-industrial urbanity, this dark side adds value through a sense of edginess or grittiness (Hetherington 2007). However, not only might a sense of danger cause people to avoid canals, but also the dark heritage of Manchester can, while attempting to fairly reflect the subjugation of working people also seem to celebrate it. At the very least it often ignores their agency, their resourcefulness, their culture and their expression as individuals. The material legacy of their leisure time - pubs, chip shops, clubs, churches, political activism, education and sports - are all removed, as the associated buildings have been demolished in successive waves of redevelopment (Rose, Falconer, and Holder 2011, 66). While others have been concerned by the avoidance of dark pasts of inequality and exploitation we find that incorporating them in celebratory or ambivalent ways can also help to reproduce inequality in the present.

Some residents actively resist the totalisation of the 'urbane' heritage regime. The Ancoats Dispensary Trust is a community-led group formed to campaign against the planned demolition of the Ancoats Dispensary, a former clinic in New Islington. The campaigners argued for the preservation of the building as an important part of local heritage, a remnant of the everyday life of local people. The Ancoats Dispensary Trust's website stresses its importance as an 'emotional touchstone' for local people. Though it began as a cottonindustry funded clinic, it became a publicly-funded hospital, and is thus part of another popular British legend, the foundation of the National Health Service. This group also staged an exhibition about the Molineaux Webb glass factory in 2016 (Ancoats Dispensary Trust 2016), highlighting heritage beyond heavy industry. The Dispensary building lies empty and partly demolished at the time of writing. The interior has been dismantled and only the external shell remains, thanks to the campaign. Funds to fully restore the building have not yet been found. Home-made signs pinned to the hoardings around it act as heritage interpretation panels, celebrating the pioneering work on hay fever and other conditions that took place in the hospital. On online forums and social media sites such as Manchester Forum[3], Pinterest and Flickr people share memories of visiting the nit nurse there or going for childhood vaccinations. These activities show there is an appetite for a kind of heritage that is not being catered for in the redevelopments. They also point to the need to see alternative forms 'on the ground', as panels, exhibitions or bricks and mortar, as well online. 
Another example of a lost 'emotional touchstone' is the New Islington Baths. It was built in 1880 and became one of a network of public pools, which hosted swimming galas, championships and water polo matches, and the world's first swimming record was recorded there in 1889 (Love Withington Baths 2017). Residents of Victoria Square told us of trips to the Baths, and it is the subject of many reminiscences on local history forums. The baths were demolished when the area was redeveloped in the 1960s (Rose, Falconer, and Holder 2011). Saved by a popular campaign, Withington Baths (in south Manchester) is the only surviving part of this historic network of large and ornate Victorian and Edwardian bath houses. In the absence of their once significant physical presence on the ground, there remains only local knowledge, photographs and other related ephemera in private archives, such as those of the local newspaper.

Despite the dominance of one heritage discourse, the canals are an available resource for leisure activities. Many people run, cycle and walk the towpaths; others go boating. Volunteering, for example to remove litter from the paths and water, can also be seen as a leisure activity. The Ancoats Canal Project members, for example were on the whole not interested in organising community events or recruiting more members, though they saw these as worthwhile activities. But they spoke about the satisfaction or enjoyment of coming once every few weeks to weed the towpath or pick litter and then go home, activities which were carried out as individuals, though alongside others. In the Lefebvrian trialectic, these may be considered as spatial practices, because they stay largely in line with the official conceived uses of the canal as a cleaned-up urban amenity. Other people expand the repertoire of leisure pursuits beyond what is officially sanctioned. Despite signs by the Chips Building in New Islington, forbidding diving and swimming in the Ashton Canal, such activities take place. People cruise for sex under certain bridges and drugs can be bought on the towpath, if you know when and where to go. These are not recognised as leisure activities in the official discourse of canal-as-amenity - the representation of space. They continue nonetheless and illicit pleasures even played a key role in the gentrification and commercial success of nearby Canal Street, as Manchester's celebrated Gay Village (see Skeggs, Moran, Tyrer, and Binnie 2004). These leisure pursuits do not find their way into the planning literature or the website of the Canal and River Trust, of course.

The canals and their towpaths were originally private property and in one way the heritagisation of canals has opened them up, by making them into public - albeit still privately owned - spaces (see Németh 2009). They are held for public use by a charity; the paths have more access points and have been resurfaced and are waterfront spaces created for people to walk and sit. However, in another way, the symbolic resources of heritage have been captured for the value they add to obsolete industrial infrastructure, and are used to generate private profit from rental, property sales and retail. This is certainly a symbolic, if not a material, enclosure. Other heritage discourses which did not fit for the purposes of property-led regeneration have been erased from the canalside, and interested local people 
have had to rebuild them virtually on social media. The campaigns to save particular buildings, such as the Dispensary, represent forays from the virtual to the material space, but in the main, the material space remains the preserve of the dominant urbane vision. This is a story of unequal power to define heritage in different spheres.

Virtual spaces are sites of far more heterogeneous, non-market forms of heritage production, underpinned by the work of amateur historians, activists and artists in the service of social needs (Gonzalez 2014; Murzyn-Kupisz and Dzialek 2013; Grant 2007). The problem would then seem to be that this online activity lacks force, and still needs to make its mark in a tangible way, on the ground. Here, in canalside spaces, heritage is mobilised by economically and politically powerful interests, in the service of private capital. This 'capture of the common value that heritage generates by the logic of private property' alienates and excludes local people (Gonzalez 2014, 366) This adds to understanding of the problem identified by the Canal and River Trust, volunteers and local residents - that despite claims in the regeneration literature that tidying up canalside areas would inevitably create vibrant communities, many people are left feeling alienated and estranged by the de-humanising processes of urban regeneration (Blakeley and Evans 2009). There is a need for sustained activity to develop local community-driven cultural heritage projects, which make residents and visitors alert to longer traditions of recreation. Festivals, heritage trails and museum displays can all shed light on longstanding enjoyment of waterscapes that preceded industrialisation and parallel stories of the industrial age, which foreground ordinary (and extra-ordinary) individuals and not just industrial and engineering might (Vallerani 2018; van den Heuvel 2016).

\section{Conclusion}

The Lefebvrian trialectic is a useful way to explain the differential power of the rich and varied range of canal heritages in Manchester and other places. While there are plural heritages, still there is a reported lack of cohesion, still some people feel pushed out and unwelcome, still many do not enjoy the heritage of the canals, which has been restored and conserved in their name. This disconnection or displacement is symbolised by the uncomfortable juxtaposition of the boats and the buildings recorded in our notes.

What is to be done? The heritage trails we created are tools with the potential to bridge the gap between the virtual and material spaces of Ancoats, and by extension other regenerating post-industrial areas. The creator of a tour draws a route on an online map, uploads any combination of text, images and audio and associates them with 'points of interest' along the route. The user can then download the tour, and with a GPS-enabled phone, the material will be triggered as they reach the points of interest. These simple tours draw down the virtual heritage into the physical space of the canal. Using an off-the-shelf app, they are also open to any member of the public to produce. Given the significant knowledge and interest of people locally, there is the potential for multiple heritages to be expressed opening up 'possibilities 
for new histories, new stories and new landscapes to emerge' (DeLyser 2014, 47). Projects such as this acknowledge and tap into the varied expertise and interests of plural communities - runners, historians, boaters and gardeners - rather than mystifying and marginalising them as an undifferentiated, singular 'community'. Unlike websites and books, using GPS technology in mobile phones, walking or boating trails explicitly map this abstract meaningmaking onto the physical spaces, and encourage an embodied engagement with the canal.

Nonetheless, the larger imbalance of power to shape canal heritage spaces still need to be addressed. Here, based on our research, we anticipate that larger changes may support a shift towards a more participatory, plural heritage culture along the canals. The Canal and River Trust, having taken over from the government's British Waterways, now has to plan for a future as an independent charity, eventually perhaps completely unfunded by central government. Donations and volunteering are key to make this sustainable. The Trust and others have begun to describe the waterways as a 'national treasure', for example in their 'About' webpage, 2017 and in their 'Strategic Waterway Plans' of 2013, which they promise to safeguard in perpetuity for the people, rather as the National Trust, the preeminent role model for heritage charities, promises in its motto to safeguard heritage 'For Ever for Everyone'. Their materials have begun to use the discourse of canals as a scenic haven, seen in the popular representations of canals on everything from jigsaws to Instagram sunsets. A line above every page of the Trust website at the moment reads 'We love and care for your canals and rivers, because everyone deserves a place to escape.' On their 'donate' page they answer the question 'why donate?' with 'We need your help to ensure that, in our increasingly fast-paced and crowded world, your canals and rivers become and remain vital local havens for both people and nature. By supporting us you can help your wonderful waterways to thrive today and ensure they're protected for future generations to enjoy' (https://canalrivertrust.org.uk/donate). There is also increasing interest in the concept of wellbeing and encouraging exercise.

For some time, it was understood that private capitalist investment dealt in private consumerist matters and that wellbeing and infrastructure was a matter for the state/local government. This has come to change in recent years, so that private, profit-making, wellbeing and civic interests merge or are seen as the same (Hetherington 2007). There is a blurring between private and public responsibilities as the role of designing, funding and managing regeneration has become shared with government, and charities like the Heritage Lottery Fund and the CRT have been brought in, the private sector began to speak the language of community and wellbeing too. The CRT told us community engagement, health and wellbeing are now central to successful funding bids (Pitt 2018). This might mean interest groups with more power to shape the canals and their surroundings will expand their repertoire beyond the quest to impress with mighty industrial buildings, inserting new representational spaces and alternative discourses to canalside leisure and living. 
The comparison in this paper then, between the mills and the boats might become not a comparison between the recognised and the neglected, but the old wave and the new wave, with the boats re-valued as a tangible manifestation of a community seeking life and livelihood on the water. The built environment has already been cleansed of the material remains of all but one conceptualisation of Manchester's canal heritage however, and creative means will need to be found to foreground and celebrate the alternatives we have discussed here.

\section{Biographical Note}

\section{Abigail Wincott}

Abigail Wincott is a former multimedia journalist and Senior Lecturer in Media and Journalism. She has published on the way ideas about the environment, nature, places like cities and networks like food systems are structured through the lens of heritage. Her recent work focuses on immersive and spatialised media technologies, and the way increasing mediatisation is changing the places where we live and work.

\section{Neil Ravenscroft}

Neil Ravenscroft is Director of the Brighton Doctoral College and Professor of Land Economy, specialising in research on people-environment relationships associated with farming, forestry and water resources. Neil's research has been funded by a number of UK research councils, including the Arts \& Humanities Research Council and the Natural Environment research Council. The foundation of his research interests lies in economic questions about the multiple relationships that people have with each other and with the natural and physical environment. At the core of this are questions about the extent to which economic concepts such as wealth, individual utility and exchange can adequately capture the complexities of such relationships.

\section{Paul Gilchrist}

Paul Gilchrist is Principal Lecturer in Human Geography at the School of Environment and Technology, University of Brighton. He has written widely on the geographies of sport, leisure and popular culture. Paul's research has been funded by the British Academy and Arts $\&$ Humanities Research Council. His research interests are in people-environment relationships, particularly the politics and history of leisure spaces, addressing concerns such as access, property rights, regulation and forms of resistance found in the public realm as people exercise rights to leisure and pleasure. 


\section{References}

Alaska TV. 2016. Series 2, episode 2, Rochdale Canal. Barging Round Britain with John Sergeant (Television programme), ITV, $29^{\text {th }}$ April.

Ancoats Dispensary Trust. 2016. Upcoming exhibition: The glory of glass in Ancoats: A hidden History. Retrieved from http://www.ancoatsdispensarytrust.co.uk/gloryofglass221.html

Ashworth, G., M. Kavaratzis and G. Warnaby, 2015. The need to rethink place branding. In M. Kavaratzis, G. Warnaby, \& G. J. Ashworth (Eds.). Rethinking place branding. Comprehensive brand development for cities and regions, 1-11. London: Springer.

Atkinson, D., S. Cooke, and D. Spooner. 2002 Tales from the Riverbank: place-marketing and maritime heritages. International Journal of Heritage Studies, 8 (1): 25-40.

Blakeley, G. and B. Evans. 2009. 'Who Participates, How and Why in Urban Regeneration Projects? The Case of the New "City" of East Manchester'. Social Policy \& Administration 43 (1): 15-32.

Briggs, A. 1963. Victorian cities. London: Odhams.

British Waterways. 2011. Waterways: Contributing to the vision for a Greater Manchester. Retrieved from https://canalrivertrust.org.uk/media/library/995.pdf

Buckman, S. 2016. Canal oriented development as waterfront place-making: an analysis of the built form. Journal of Urban Design, 21 (6): 785-717.

Button, K. J. and D. W. Pearce. 1989. Infrastructure Restoration as a Tool for Stimulating Urban Renewal-The Glasgow Canal. Urban Studies, 26 (6): 559-571.

Canal and River Trust. 2014. Water Adds Value: highlighting the impact of the restoration of our waterways. Retrieved from http://www.waterways.org.uk/waterways/restoration/restoration_resources/pdfs/water_add s_value_benefits_of_waterways_restoration

Cosgrove, D., and S. Daniels. 1988. The Iconography of Landscape. Cambridge: Cambridge University Press.

Cresswell, T. 1996. In place/out of place: geography, ideology and transgression. Minneapolis: University of Minnesota Press.

Crinson, M. and P. Tyrer. 2005. Clocking Off in Ancoats: Time and Remembrance in the Post-Industrial City. In M. Crinson (Ed.), Urban Memory: History and Amnesia in the Modern City, 49-71. Abingdon: Routledge.

De Cesari, C and R. Dimova. 2019. Heritage, gentrification, participation: remaking urban landscapes in the name of culture and historic preservation. International Journal of Heritage Studies, 25 (9): 863-869.

DeLyser, D. 2014. Tracing absence: enduring methods, empirical research and a quest for the first neon sign in the USA. Area 46 (1): 40-49.

Engels, F. 1958. The condition of the working class in England (W. O. Henderson \& W. H. Chaloner, Trans.). Oxford: Blackwell.

Fainstein, S. 2008. Mega-Projects in New York, London and Amsterdam. International Journal of Urban and Regional Research, 32 (4): 768-785.

Fairs, M. 2007, 3 June. Tutti Frutti house design competition. Dezeen. 
Florida, R. 2002. The rise of the creative class... and how it's transforming work, leisure, community, and everyday life. New York: Perseus Books.

Frolova, M. 2008. El estudio de los paisajes del agua en una cuenca vertiente: Propuesta metodológica. Revista de Estudios Regionales, 3: 21-47.

Gilchrist, P., N. Ravenscroft, N. Moore, A. Lee and C. Holmes. 2015. Co-designing nonhierarchical community arts research: the collaborative stories spiral Qualitative Research Journal, 15 (4): 459-471.

Gonzalez, P.A. 2014. From a Given to a Construct: Heritage as a Commons. Cultural Studies, 28 (3): 359-390.

Grant, L. 2007. From the Ground Up: New Islington 2001-2007. Manchester: Len Grant Photography.

Hazenberg, R., and M. Bajwa-Patel. 2014. A review of the impact of waterway restoration. Retrieved from https://canalrivertrust.org.uk/media/library/6337.pdf

Hetherington, K. 2007. Manchester's Urbis: Urban regeneration, museums and symbolic economies. Cultural Studies, 21 (4-5): 630-649.

Hoyle, B. S., M. S. Husain, and D.A. Pinder. 1988. Revitalising the waterfront: international dimensions of dockland redevelopment. London: Bellhaven Press.

Inland Waterways Advisory Council. 2010. Surviving the Cuts and Securing the Future: The funding and structure of the inland waterways in England and Wales. Retrieved from http://issuu.com/waterwaysassoc/docs/surviving the_cuts_and_securing_the_future_10_1 $\underline{0 \text { ? mode }=\text { window } \& \text { view Mode }=\text { doublePage }}$

Joseph, A., R. Kearns, and G. Moon. 2013. Re-imagining psychiatric asylum spaces through residential redevelopment: strategic forgetting and selective remembrance. Housing Studies 28 (1): 135-153. doi:10.1080/02673037.2013.729270.

Kearns, R., A. E. Joseph, and G. Moon. 2010. Memorialisation and remembrance: on strategic forgetting and the metamorphosis of psychiatric asylums into sites for tertiary educational provision. Social \& Cultural Geography, 11 (8): 731-749. doi:10.1080/14649365.2010.521852.

Kennedy, L. 2004. Introduction: The creative destruction of Birmingham. In L. Kennedy (Ed.), Remaking Birmingham: the visual culture of urban regeneration, 1-11. London and New York: Routledge.

Larkham, P.J. and K. D. Lilley. 2003. Plans, planners and city images: place promotion and civic boosterism in British reconstruction planning. Urban History 30 (2): 183-205.

Leeson, L. 2018. Our land: creative approaches to the redevelopment of London's Docklands. International Journal of Heritage Studies, 25 (4): 365-79. DOI: 10.1080/13527258.2018.1485166

Lefebvre, H. 1991. The Production of Space. D. Nicholson-Smith (Trans). Oxford, UK and Cambridge, USA: Blackwell.

Lewery, T. 1995. Rose, Castle and Canal: An Introduction to the Folk Art of English Narrow Canal Boats. Folklore, 106: 43-56.

Love Withington Baths. 2017. The history of public swimming baths in Manchester. Retrieved from http://www.lovewithingtonbaths.com/about-withington-baths.html 
Lucarelli, A. 2017. Place branding as urban policy: The (im)political place branding. Cities 80: 12-21. http://dx.doi.org/10.1016/j.cities.2017.08.004.

Lutz, J. 2004. The Altered Eye: the European Capital of Culture Bid and Visual Images of Birmingham. In L. Kennedy (Ed.), Remaking Birmingham: the visual culture of urban regeneration, 123-132. London and New York: Routledge.

Madgin, R. 2010. Reconceptualising the historic urban environment: conservation and regeneration in Castlefield, Manchester, 1960-2009. Planning Perspectives, 25 (1): 29-48.

Maw, P. 2013. Transport and the Industrial City: Manchester and the Canal Age, 1750-1850. Manchester: Manchester University Press.

Maw, P., T. Wyke, and A. Kidd. 2009. Warehouses, Wharves and Transport Infrastructure in Manchester during the Industrial Revolution: The Rochdale Canal Company's Piccadilly Basin, 1792-1856. Industrial Archaeology Review, 31 (1): 20-33.

Mellor, R. 2002. Hypocritical City: cycles of urban exclusion. In J. Peck \& K. Ward (Eds.), City of Revolution: Restructuring Manchester, 214-235. Manchester and New York: Manchester University Press.

Mengüssoğlu, N. and E. Boyacioğlu. 2013. Reuse of industrial built heritage for residential purposes in Manchester. METU Journal of the Faculty of Architecture 30 (1): 117-138.

Meskell, L. 2018. Heritage, gentrification, participation: Remaking urban landscapes in the name of culture and historic preservation. International Journal of Heritage Studies, 25 (9): 996-998. DOI: 10.1080/13527258.2018.1542334.

Murzyn-Kupisz, M. and J. Działek, J. 2013. Cultural Heritage in Building and Enhancing Social Capital. Journal of Cultural Heritage Management and Sustainable Development, 3(1): 35-54.

Németh, J. 2009 Defining a public: the management of privately owned public space. Urban Studies 46 (11): 2463-2490.

Nevell, M. 2013. Bridgewater: The archaeology of the first arterial industrial canal. Industrial Archaeology Review, 35 (1): 1-21.

O'Gorman, S., C. Bann and V. Caldwell. 2009. The Benefits of Inland Waterways. Retrieved from http://www.waterwaysforward.eu/wp-content/uploads/2012/06/The-Benefits-ofInland-Waterways_Final-ReportJuly-2009 JACO.pdf

Pendlebury, J., T. Townshend, and R. Gilroy. 2004. The conservation of English cultural built heritage: a force for social inclusion? International Journal of Heritage Studies, 10 (1): 11-31.

Pendlebury, J., Y-W Wang, and A. Law. 2017. Re-using 'uncomfortable heritage': the case of the 1933 building, Shanghai. International Journal of Heritage Studies, 24 (3): 211-29. DOI: $10.1080 / 13527258.2017 .1362580$

Pierce, J. and D. G. Martin. 2015. Placing Lefebvre. Antipode, 47 (5): 1279-1299.

Pitt, H. 2018. Muddying the Waters: What Urban Waterways Reveal about Bluespaces and Wellbeing. Geoforum, 92: 161-170.

Rautenberg, M. 2011. Industrial heritage, regeneration of cities and public policies in the 1990s: elements of a French/British comparison. International Journal of Heritage Studies 18: $1-12$. 
Rea, A. 1988. Manchester's Little Italy. Manchester: Neil Richardson Publications.

Rose, M. E., K. Falconer, and J. Holder. 2011. Ancoats: Cradle of industrialisation: English Heritage.

Schama, S. 1995. Landscape and Memory. New York: Alfred A. Knopf.

Skeggs, B., L. Moran, P. Tyrer, and J. Binnie. 2004. Queer as Folk: Producing the Real of Urban Space. Urban Studies, 41 (9): 1839-1856.

Spungold TV. 2014. (Television programme) Series 1, episode 2: The Rochdale. Great Canal Journeys, Channel 4, 17 March.

Taylor, Y. 2013. (Dis)Orientations in Past, Present, and Future Encounters. Qualitative Inquiry, 19 (10) : 828-838.

Vallerani, F. 2004. Acque a nordest. Da paesaggio moderno ai luoghi del tempo libero. Verona: Cierre.

Vallerani, F. (2018). Introduction: Flowing Consciousness and the Becoming of Waterscapes. In F. Vallerani and F. Visentin (Eds.) Waterways and the Cultural Landscape, 1-16. Abingdon: Routledge.

Van den Heuvel, M., ed. 2016. Blue Bliss: The Art of Enjoying Water. Zwolle: WBooks.

Vanolo, A. 2017. City branding. The ghostly politics of representation in globalising cities. London: Routledge.

Visentin, F. and E. Eulisse, E. 2018. Digital Applications and River Heritage: The Inherited Landscape of Venice's Historic Waterways. In F. Vallerani and F. Visentin (Eds.) Waterways and the Cultural Landscape, 229-243. Abingdon: Routledge.

Visentin, F. and G. Peterle. 2017. Performing the Literary Map: 'Towards the River Mouth' Following Gianni Celati. Cultural Geographies, 24: 473-485.

Ward, K. and E. Swyngedouw. 2018. Neoliberalisation from the Ground Up: Insurgent Capital, Regional Struggle, and the Assetisation of Land. Antipode, online first.

Waterton, E. 2010. Branding the Past: The Visual Imagery of England's Heritage. In E. Waterton \& S. Watson (Eds.), Culture, Heritage and Representation: Perspectives on Visuality and the Past, 155-172. Farnham: Ashgate.

Waterton, E. and L. Smith. 2010. The recognition and misrecognition of community heritage. International Journal of Heritage Studies, 16 (1-2): 4-15. doi/abs/10.1080/13527250903441671.

Young, A. 2003. Paint roses and castles. Traditional narrow boat painting for homes and boats. Newton Abbott, Devon: David \& Charles.

Zukin, S. 1995. The Cultures of Cities. Cambridge, MA: Blackwell.

Figures

Figure 1) 
Figure 2

Figure 3

Figure captions

1. Castles and Roses artwork on a canal boat, photo by David Dixon (CC BY SA 2.0)

2. Piccadilly Village development, Ashton Canal. Photo by Benjamin Shaw (CC BY-SA 4.0)

3. Mills on present-day Redhill Street, Ancoats. From A Century of fine Cotton Spinning, 1790-1913. McConnel \& Co. Ltd. Photo Wikimedia Commons

Word count 7971

4. Chips Building, Ancoats. Photo by David Jones (CC BY 2.0)

[1] The images can be seen on the project's website at waterwaysexplorer.org

[2] The trails, branded 'Waterways Explorer', can be found by visiting https://izi.travel/en/search/waterways\%20explorer and they include trails produced after the end of the project by community groups keen to continue the work, such as the Daisy Nook Canal Trail in Greater Manchester.

[3] http://www.manchester-forum.co.uk/index.php?topic=9093.0 